\title{
Preface to Islamic Political Psychology: Siyasah Syariyyah Meets Psychology
}

\author{
Khairul Azmi Mohamad ${ }^{1}$, Nooraini Othman ${ }^{1}$ \& Ghazali Jaapar ${ }^{2}$ \\ ${ }^{1}$ Perdana Centre, Razak Faculty of Technology \& Informatics, Universiti Teknologi Malaysia, Malaysia \\ ${ }^{2}$ Kulliyyah of Laws, International Islamic University Malaysia, Malaysia \\ Correspondence: Nooraini Othman, Perdana Centre, Razak Faculty of Technology \& Informatics, Universiti \\ Teknologi Malaysia, Jalan Sultan Yahya, 54100 Kuala Lumpur, Malaysia. Tel: 60-7-2180-5157. E-mail: p- \\ noraini@utm.my
}

Received: April 26, 2020

Accepted: July 7, $2020 \quad$ Online Published: August 17, 2020

doi:10.5539/jpl.v13n3p38

URL: https://doi.org/10.5539/jpl.v13n3p38

\begin{abstract}
This paper attempts to decribe what is Islamic political psychology. The coverage of this paper is preliminary in nature. The study of political psychology came into picture as a discipline of study quite recently. It is a combination of political science and psychology. It is timely to have the study of Islamic Political psychology. If the study of political psychology involves the theories and practice of political science and psychology, necessarily the Islamic political psychology involves the theories and practice of Islamic Politics (siyasah syariyyah) and Islamic psychology ('ilm nafs al-Islami). This paper intends to look at the principles of Islamic politics and its relationship to Islamic psychology. It will also be describing the characteristic features of politics from the perspective of syariah. The principles that underline the political system of Islam will then be elaborated. This paper will attempt to highlight the similarities and differences between political psychology as perceived by the coventional perspective and the study as expounded by the worldview of Islam. Islamic political psychology will help the understanding of a certain pattern of thinkings and behaviours either of the politicians or the people as they relate to politics.
\end{abstract}

Keywords: political psychology, Islamic political psychology, Siyasah syariyyah, Islamic psychology

\section{Introduction}

The challenge of this paper is to come up with at least an acceptable definition of what is Islamic Political Psychology. The study of political psychology in the West or in its conventional sense has been quite deep and far. The study of Islamic politics or siyasah syariyyah is very established. However, marrying siyasah syariyyah with Islamic psychology is a truly a novel effort. This does not mean that the elements of psychology had never been discussed anywhere at all while the study of siyasah syariyyah is made. It is more of not being admitted as specific discipline bearing the name Islamic political psychology. Just like Islamic psychology. The elements of Islamic psychology had been present since a very long time ago. The sufis had been speaking and deliberating about purification of heart which is essentially psychological in nature without the label of Islamic psychology being attached to it. In Arabic, Islamic psychology is closely translated as 'Ilm al-nafs al-Islami. Only in recent years the effort to consolidate and coin the subject matter as Islamic psychology. Now it is perhaps the turn to see the possibility of having the marriage of Islamic psychology and siyasah syariyyah or Islamic politics to form Islamic political psychology. It is verily a humble beginning.

\section{Methodology}

This work is comprative in nature. It builds upon the concepts of Political Psychology as established in the West and comparatively reviewed from the perspective of Islamic Politics in view of coming up with a new understanding on Islamic Political Psychology. The study is based on a surveyed literature coming from both disciplines. This study is preliminary in nature.

\section{Preface to Political Psychology}

The subject of political psychology is not as popular as the subject of political science itself in Malaysia. Politics in Malaysia are much scientifically analysed from the perspectives of sociology and political science. In the Western countries, the study of political psychology dated back even earlier than the World War 1. Harold D. 
Lasswell from the University of Chicago wrote in 1925 highlighting two works of importance. The two work which he regarded as being forgotten were written in the year 1758 by Dr. J.G. Zimmerman - Essay On National Pride, published at Zurich, describing the nature of patriotism and international attitudes. It was also regarded as a departure from the normal discussion of politics. In the year 1822, published at Cologne, Gottfried Dudden made inquiry, Concerning the Essential Differences of States and the Motives of Human Nature.

Since World War 2, many empirical research conducted by social scientists in Europe including in the field of psychology. Maurice L. Farber, a psychologist from the University of Connecticut reviewed the work of a Norwegian social psychologist, Bjorn Christiansen, Attitudes Towards Foreign Affairs as a Function of Personality, published in 1959. It is purely a psychological book studying the political attitudes.

In 1983, UNESCO published a collection of works under its International Social Science periodical label, Political Dimension of Psychology: Socialization Process and Identities. Many works, authoritative in nature had been included in this publication. The topics including what are Political Psychology; Political Socialization; Political Engineering; and Community Psychology.

Morton Deutsh (1983), a Professor of Psychology and Education at Teachers College, Columbia University made a significant observation.

\begin{abstract}
Although its ancestry in social philosophy can be traced back to ancient times, modern political psychology as an academic discipline was born in the decades between the First and Second World Wars. It is a child of political science and psychology, having been conceived in the ambivalent mood of optimism and despair, which has characterized the scientific age. Rapidly expanding knowledge, the increasing confidence in scientific methods and the ever-quickening technological developments stimulated the awareness that scientific methods might be applied to the understanding of political behaviour.
\end{abstract}

Morton Deutsh (1983) observed that the first identifiable linkage as far as psychology and political science are concerned in the United States took place at the University of Chicago as a result of strong motivation from the visionary political scientist Charles Merriam. Some of Charles Merriam notable works are New Aspects of Politics (1925) and Political Power (1934). Merriam unequivocally urged for a scientific analysis on political science reflecting on psychology. Professor Merriam's desciple by name of Harold D. Lasswell made a significant respond to his teacher's call. He incorporated political psychology in his works and lectures. Lasswell was later recognised as the American founding father of political psychology as a new academic discipline.

Although Lasswell's prolific writings spread over many areas of interest in political psychology, his works on psychological processes as they influenced political processes has been prominent and influential in framing and leading the way most American social scientists in their journey to appreciate the domain of political psychology. He published many books drawing reflection on political psychology such as Psychopathology and Politics, published in 1930, World Politics and Personal Insecurity, published in 1935, Politics: Who Gets What, When, and How, published in 1936, Power and Personality, published in 1948, catalysed the inauguratation of a distinctive psychological worldview for comprehending the knowledge of political behaviour, politics and politicians. Such worldview moved political psychology to largely be centred on individual and social psychological fields covering the areas of conflict, motivation and perception. It also touches the areas of cognitive, learning and socialisation. It also affects attitude building and group dynamics as well as individual personality and psychopathology. All of them formulated the seminal components shaping political behaviour.

Jeanne N. Knutson played a significant role to solidify political psychology as a distinct discipline by itself. Knutson contributed to the field by editing the first major publication being her effort to establish and expound political psychology, namely the Handbook of Political Psychology, published in 1973. The work incorporated psychology, sociology, and political science. Her significant contribution continued further as she established the International Society of Political Psychology in 1978 as its founder. The Society published its own journal called Political Psychology and its first edition was published in the very same year. The field progressed further. The field of political psychology although young in nature gained strong momentum and started to respond to current issues (Stone et. all, 2014).

\title{
4. Defining Political Psychology
}

There are two important factors merit consideration:

Social and cultural lives are indissociable from the threads that make up the fabric of the human Psyche. The very forefathers of Psychology did not fail in acknowledging this. (Valsiner and Rosa, 
2007).

Individuals are not merely passive vessels of whatever beliefs and opinions they have been exposed to; rather, they are attracted to belief systems that resonate with their own psychological needs and interest (Tost, 2017).

According to Deutsh (1983):

the field of political psychology is the study of the interaction of political and psychological processes. It is not only to its subject matter but also to its scientific methodology.

According to Martha Cottam et. all, (2004):

both psychologists and political scientists have become interested in expanding their knowledge of issues and problems of common interest, such as foreign and domestic policy decision making by elites, conflicts ranging from ethnic violence to wars and genocide, terrorism, the minds of people who are racists, and more peaceful behaviours such as voting behaviour, among many other issues and problems traditionally of concern to political science.

Political psychology is essentially a field of study that synergises two distinct disciplines, namely politics and psychology. The marriage of the two disciplines reflects its paramount importance and the proximity as well as the relationship of the two towards one another.

Political misperceptions can distort public debate and undermine people's ability to form meaningful opinions. Political perceptions are typically rooted in directionally motivated reasoning, which limits the effectiveness of corrective information about controversial issues and political figures. (Flynn, et all., 2017).

Thus, political psychology is an important aspect to be studied from the Islamic perspectives.

\section{The Basics of Islamic Politics}

Politics is one of the most important organs in the administration of a country in Islam. It relates among others to the aspects of leadership, policy, administration, governance, government and programmes. Islamic politics is the politics based on the tenets of syariah. The sources of Islamic politics are divided into two, the Divine and the intellectual exertion of the Divine sanctions. The Divine sacntions, namely the Quran and Sunnah are regarded as the primary sources. The second category, regarded as the secondary sources are Ijtihadi (juristic rulings) in nature - i.e. the syariah rulings being derived from the Divine sanctions by the scholars of Islamic knowledge (ulama) using the Islamic jurisprudential methodology known as usul al-fiqh. Generally they are Ijma (consensus of jurists) and qiyas (analogy). There are other sources of ruling such as masalih mursalah (public interest) and istihsan (juristic preference).

The study of Islamic politics is commonly known as al-siyasah al-syariyyah. The word siyasah literally means administering a particular matter or a leader administering his people. Siyasah syariyyah could immediately give an understanding that it is the administration of people's affairs based on the principles of syariah.

According to Abdul Wahab Khallaf (1982), siyasah syariyyah is about managing the interest (maslahah) of the people according to the determination of syariah. It aims at bringing goodness (manafi') and avoiding evil (mafsadah). The discussion surrounds the system, regulations and laws needed in the management and successful running of a country following the precepts of Islam with the intention of attaining benefits for all. This policy runs in conformity with the qawaid fiqhiyyah (maxim), Dar-ul Mafasid Muqaddam 'an Jalb al-Manafi' - The avoidance of harm is preferred over the quest for goodness.

The intention of siyasah syariyyah is to achieve the higher objective of syariah termed as maqasid syariah. Maqasid syariah is famously expounded by al-Ghazali in his work al-mustasfa, to mean the fundamental protections (hifz) of the Religion of Islam (deen), life (nafs), property (mal), progeny (nasl) and intellect ('aql). Sultanul ulamak - 'Izzuddeen Abdul Salam in his work qawaid al-ahkam fi masalihi al-anam broadened the discussion of maqasid in terms of promoting benefit and preventing harm. Imam Shatibi further developed the theory of maqasid by focusing on the concept of maslahah or public interest by looking at the intent and purpose of the Divine laws, which are intended to preserve human interests in both this world and the next. (Rane, 2013).

Ultimately, what siyasah syariyyah intends to achieve is the creation of khayra ummah. Khayra ummah is a concept enshrined in the Quran to mean the best ummah. The best ummah or Muslim community could only be attained through best individual or best personality. In order to be khayra ummah, the Quran said, they should be exercising al-amru bi al-ma'ruf or enjoining good deeds, exercising nahyu 'an al-munkar or forbidding evils and finally alIman billah or having faith in Allah. This is in line with the Quranic verse in surah Ali 'Imran verse 110, which means: You are the best people ever raised up for mankinds; you enjoin al-ma'ruf and forbid al-munkar and believe 
in Allah.

It is interesting and much could be learnt when we want to understand the direction of Islamic politics by observing the work of Ibnu Khaldun. Ibnu Khaldun is known through out the world as the world expert on history, sociology and also civilisation. Perhaps not much exposed to many, Ibnu Khaldun possessed an in-depth political thought and very valuable to be understood as well as observed in many forms. Only a small part will be highlighted here. M. Umar Chapra recorded and analysed Ibnu Khaldun's seminal work al-Muqaddima - the work completed in November 1377 - and made relations to the followings.

The strength of the sovereign (al-mulk) does not become consummated except by the implementation of the syariah;

The syariah cannot be implemented except by a sovereign (al-mulk);

The sovereign cannot gain strength except through the people (al-rijal);

The people cannot be sustained except by wealth (al-mal);

Wealth cannot be acquired except through development (al-imarah);

Development cannot be attained except through justice ( $a l$ - 'adl);

Justice is the criterion (al-mizan) by which God will evaluate mankind; and

The sovereign is charged with the responsibility of actualizing justice.

He further states that the advice consists of (in Ibnu Khaldūn's own words) "eight wise principles [kalimat hikamiyyah] of political wisdom, each one dovetailed with the other for mutual strength, in such a circular manner that the beginning or the end is indistinguishable". It reflects the interdisciplinary and dynamic character of Ibnu Khaldun's analysis.

\section{Islamic Political Psychology}

In the tradition of Islamic politics, power and position are not the aims of political struggle. They are the wasilah or bridge for a higher aim that is to serve the promotion of benefit and preventing harm to attain the pleasure of Allah (Mardhatillah). Politics is an initiative to achieve maqasid syariah. It is practised on the basis of maslahah. In the context of Islamic political psychology, it has to directly adopt the principles of Islamic Psychology. Islamic psychology is the study of mind, behaviour and spiritual well-being of the Muslim based on Quran and Sunnah.

Islamic political psychology could be defined as the application of Islamic psychology to siyasah syariyyah towards achieving the maqasid syariah to ultimately produce khayra ummah and hadharah (civilisation). The higher objective in Islamic politics should be about building civilisation. The civilisation built by the khayra ummah will certainly be a model civilisation.

The striving of the Muslim politician towards attaining the higher objective of syariah or maqasid syariah would characterise whether his practice of politics is Islamic or not. That would be a measure to his leadership. His political mind and behaviour must conform to the teachings of Islam. Therefrom, his leadership behaviour will be able to command political trust by the grace of Allah. The ideal leadership behaviour was demonstrated by Prophet Muhammad through his exemplary character namely siddiq (truthful), amanah (trustworthy), tabligh (communicate) and fathonah (wisdom).

To this end we believe that the task of Muslim psychologist is tremendously big especially in the context of Islamic political psychology. Not just about expanding the study, but it is more of developing a good Muslim political personality.

\section{Conclusion}

The discipline of Islamic politics is already established. It is part of the syariah system. Hence it is called alsiyasah al-syari'yyah. The study of Islamic politics is jurisprudential (fiqhi) in nature. The theories and principles of Islamic politics are well defined and expounded by the scholars of Islam. They rest in volumes of works by these scholars. The premise of this discipline is the Quran and Sunnah.

The discussion on Islamic politics from the perspective of psychology in the modern context is indeed something very new. This paper is humbly attempting to set an initial basic understanding to the field. The authors believe there should be a way forward to turn Islamic political psychology as a sub-discipline to Islamic psychgology.

The growth of Islamic political psychology will help to enrich the understanding for both, the Islamic psychologist and political scientist, on many areas where they are not familiar with. The Islamic political psychologists who have the mastery of both disciplines, Islamic psychology and Islamic politics, would be able to analyse and share 
their perspectives on a particular political thinkings and behaviours either of the politicians or the people as they relate to politics. Theories, concepts and empirical analysis from the Islamic political psychology perspective would be expected to give rise to different answers and conclusions. A further analysis in the future works will help to elaborate the subject matter further.

\section{Acknowledgments}

Appreciation goes to the Ministry of Education Malaysia under the sponsorship of Fundamental Research Grant Scheme (FRGS - 05F018).

\section{References}

Abdul, W. K. (1982). Siyasah syariyyah Aw Nizam al-Daulah Islamiyyah Fi Syuun al-Dusturiyyah wa alKharijiyyah wa al-maliyah. Kaherah, Dar al-Ansar.

Chapra, M. U. (1999). Socioeconomic and Political Dynamics in Ibnu Khaldūn's Thought. The American Journal of Islamic Social Sciences, 16(4), 17-38.

Cottam, M., Dietz-Uhler, B., Mastors, E. M., \& Preston, T. (2004). Introduction to Political Psychology. London, Lawrence Erlbaum Associates, Publishers. https://doi.org/10.4324/9781410609885

Deutsh, M. (1983). What Is Political Psychology, in UNESCO. Political Dimension of Psychology: Socialization Process and Identities. International Social Science Journal, XXXV(2), 221-236.

Farber, M. L. (1960). Toward a Psychology of Political Behaviour. The Public Opinion Quarterly, 24(3), 458-464. https://doi.org/10.1086/266964

Flynn, D. J., Nyhan, B., \& Reifler, J., (2017). The Nature and Origin of Misperceptions: Understanding False and Unsupported Beliefs About Politics. Political Psychology, 38(2), 127-150. https://doi.org/10.1111/pops. 12394

Halim, R. (2013). The Relevance Of A Maqasid Approach For Political Islam Post Arab Revolutions. Journal of Law \& Religion, XXVIII, 489-520. https://doi.org/10.1017/S0748081400000126

Ibnu, A. (1992). Hasyiah Radd al-Mukhtar 'ala al-Durr al Mukhtar. Juz 4, Beirut.

Lasswell, H. D. (1925). Two Forgotten Studies in Political Psychology. The American Political Science Review, 19(4), 707-717. https://doi.org/10.2307/2939161

Merriam, C. (1925). New Aspects of Politics. Chicago: University of Chicago Press.

Merriam, C. (1934). Political Power. New York, Collier.

Stone, S., Johnson, K. M., Beall, E., Meindl, P., Smith, B., \& Graham, J. (2014). Political psychology. John Wiley \& Sons, Ltd. https://doi.org/10.1002/wcs.1293

Tost, J. T. (2017). Ideological Asymmetries and the Essence of Political Psychology. Political Psychology, 38(2), 167-208. https://doi.org/10.1111/pops. 12407

UNESCO. (1983). Political Dimension of Psychology: Socialization Process and Identities. International Social Science Journal, $X X X V(2)$.

Valsiner, J., \& Rosa, A. (2007). The Cambridge Handbook of Sociocultural Psychology. United Kingdom: Cambridge University Press.

\section{Copyrights}

Copyright for this article is retained by the author(s), with first publication rights granted to the journal.

This is an open-access article distributed under the terms and conditions of the Creative Commons Attribution license (http://creativecommons.org/licenses/by/4.0/). 